\title{
TIPE-TIPE KALIMAT MAJEMUK SETARA DALAM BAHASA JAWA NGOKO
}

\author{
Ari Wulandari \\ Universitas Gadjah Mada, Yogyakarta, Indonesia \\ E-mail: kinoysan@yahoo.com
}

\begin{abstract}
This study aims to describe the types of the structure and relationship between clause of compound sentences in the lowest level Javanese. Compound sentence is a sentence that has parallel clause relationship, equal, or not having a subordinate clause. Data are obtained from the intuition of researcher as Javanese speakers and listening to Javanese conversations. Data analysis was performed by the distributional techniques to identify the structures and identity techniques to clarify the constituents. The results obtained is that the compound sentence consists of two main things. The ones which based on its structure consist of four types, namely: (1) Subject Predicate (Object) (Complement) (Adverb) $+S P(O)(C)(A)+S P(O)(C)(A),(2) S P 1+P 2+P 3$, (3) P1 + S1P2 (+P3), and (4) S1P1 + S2. While the others which based on the relationship clause, consist of five types, namely: (1) the sum relationship, (2) the choice relationship, (3) the resistance relationship, (4) the excessive relationship, and (5) the continuous relationship.
\end{abstract}

Keywords: clauses relationship, compound sentence, distributional techniques, identification techniques, the lowest level of Javanese

\begin{abstract}
Abstrak: Penelitian ini bertujuan mendeskripsikan tipe-tipe struktur dan hubungan antarklausa kalimat majemuk dalam bahasa Jawa ngoko. Kalimat majemuk adalah kalimat yang hubungan klausanya paralel, sama atau tidak memiliki klausa bawahan. Data diperoleh dari intuisi peneliti sebagai penutur bahasa Jawa serta menyimak percakapan yang berlangsung dalam bahasa Jawa. Data dianalisis menggunakan teknik distribusi untuk mengidentifikasi struktur dan teknik identitas untuk memperjelas konstituen. Hasil yang diperoleh dalam penelitian ini adalah pada kalimat majemuk terdapat dua hal yang utama, yang berdasarkan struktur terdiri atas empat jenis, yaitu: (1) Subyek Predikat (Obyek) (Pelengkap) (Keterangan) + SP(O) (Pel) (Ket) + $\mathrm{SP}(\mathrm{O})(\mathrm{Pel})(\mathrm{Ket}),(2) \mathrm{SP} 1+\mathrm{P} 2+\mathrm{P} 3,(3) \mathrm{P} 1+\mathrm{S} 1 \mathrm{P} 2(+\mathrm{P} 3)$, and (4) S1P1 + S2. Sementara itu, yang berdasarkan hubungan klausa, terdiri dari lima jenis, yaitu: (1) hubungan penjumlahan, (2) hubungan pilihan, (3) hubungan perlawanan, (4) hubungan berlebihan, dan (5) hubungan yang terus menerus atau berkesinambungan.
\end{abstract}

Kata Kunci: hubungan klausa, kalimat majemuk, teknik distribusi, teknik identifikasi, bahasa Jawa ngoko

Permalink/DOI: http://dx.doi.org/10.15408/dialektika.v3i1.4179 


\section{Pendahuluan}

Bahasa Jawa adalah bahasa yang sangat kompleks yang digunakan oleh suku Jawa untuk berkomunikasi. Secara sederhana bahasa Jawa dapat digolongkan menjadi bahasa Jawa ngoko, bahasa Jawa krama (lebih halus), dan bahasa Jawa krama inggil (sangat halus) dengan pemilahan masing-masing yang menyebabkan bahasa Jawa menjadi bahasa yang sangat kompleks, baik aturan maupun ketentuan penggunaannya.' Bahasa Jawa yang digunakan dalam penelitian ini adalah bahasa Jawa ngoko, yaitu bahasa Jawa tingkat paling rendah yang digunakan oleh sesama penutur Jawa yang memiliki kedudukan setara, seimbang, sejajar baik dalam umur maupun tataran kelas sosial.

Pilihan objek penelitian pada bahasa Jawa ngoko karena jenis tuturan inilah yang paling banyak digunakan dalam kehidupan sehari-hari. Pada penelitian ini akan dikemukakan tipe-tipe kalimat majemuk setara dalam kerangka kajian sintaksis. Sintaksis ialah bagian atau cabang dari ilmu bahasa yang membicarakan seluk beluk wacana, kalimat, klausa, dan frase; berbeda dengan morfologi yang membicarakan seluk beluk kata dan morfem. ${ }^{2}$ Bahan penelitian kajian sintaksis dapat berupa frase, klausa, kalimat, dan wacana.

Di dalam pertuturan atau karangan, bahasa itu diwujudkan dalam bentuk satuan-satuan bahasa yang disebut kalimat. Kalimat-kalimat ini secara teoretis dibentuk oleh unsur subjek $(\mathrm{S})$, predikat $(\mathrm{P})$, objek $(\mathrm{O})$, dan keterangan $(\mathrm{K})$. $\mathrm{S}$ adalah bagian dari kalimat yang merupakan pokok pembicaraan. $\mathrm{P}$ adalah bagian dari kalimat yang memberi penjelasan mengapa, bagaimana, atau apa yang terjadi terhadap pokok pembicaraan itu. $\mathrm{O}$ adalah bagian kalimat yang memberi penjelasan terhadap kejadian yang menyangkut pokok pembicaraan. $\mathrm{K}$ adalah bagian kalimat yang memberi penjelasan tambahan mengenai kapan, di mana, atau dalam keadaan apa peristiwa yang dialami pokok pembicaraan itu sedang berlangsung. ${ }^{3}$

Unsur-unsur S, P, O, K masing-masing dapat berwujud sebuah kata, tetapi dapat juga berwujud dua buah kata atau lebih yang merupakan satu kesatuan dan disebut frase. Frase adalah gabungan dua buah kata atau lebih yang merupakan satu kesatuan, dan menjadi salah satu unsur atau fungsi kalimat ( $\mathrm{S}$,

\footnotetext{
${ }^{1}$ Wedhawati, dkk., Tata Bahasa Jawa Mutakhir, (Yogyakarta: Kanisius, 2006), h. 10.

${ }^{2}$ Ramlan, Morfologi, (Yogyakarta: CV. Karyono, 1996),h. 21.

${ }^{3}$ Abdul Chaer, Tata Bahasa Praktis Bahasa Indonesia, (Jakarta: Rineka Cipta, 1998), h. 300.
} 
$\mathrm{P}, \mathrm{O}$, atau K). ${ }^{4}$ Unsur-unsur penentu $\mathrm{S}, \mathrm{P}, \mathrm{O}, \mathrm{K}$ tersebut baru dapat diketahui fungsinya setelah bergabung dengan unsur yang lain dalam kalimat.

Struktur kalimat majemuk setara dalam bahasa Jawa ngoko sangat menarik dikaji karena terdapat aneka kalimat majemuk setara yang dipakai sehari-hari di lingkungan sekitar peneliti. Penelitian ini mengemukakan aneka macam kalimat majemuk setara dalam bahasa Jawa ngoko.

Kalimat majemuk adalah kalimat yang terdiri lebih dari satu klausa. Kridalaksana membedakannya menjadi dua macam. Kalimat yang terjadi dari beberapa klausa bebas dinamakan kalimat majemuk, sedangkan kalimat yang terjadi sekurang-kurangnya satu klausa bebas dan sekurang-kurangnya satu klausa terikat disebut kalimat bersusun atau kalimat kompleks. ${ }^{5}$ Artinya kalimat yang terdiri atas lebih dari satu klausa yang hubungan antarklausanya koordinatif disebut kalimat majemuk, sedangkan yang hubungan antarklausanya bersifat subordinatif disebut kalimat kompleks.

Berbeda dengan Lyons yang menjelaskan bahwa kalimat yang unsurunsurnya terdiri lebih dari satu klausa adalah kalimat kompleks. ${ }^{6}$ Adapun Ramlan memberi istilah kalimat majemuk untuk kalimat yang terdiri dari dua klausa atau lebih. Batasan yang sama juga diberikan oleh Keraf yaitu kalimatkalimat yang mengandung dua pola kalimat atau lebih adalah kalimat majemuk. $^{8}$

Sementara itu, yang dimaksud dengan kalimat majemuk setara adalah kalimat majemuk yang hubungan antarklausanya sejajar, setara, tidak bawah membawahi. Hubungan antarkalusa itu secara formal dapat ditandai dengan jeda atau kata perangkai lan 'dan', lan uga 'dan juga', lan maneh 'dan lagi', sarta 'dan, serta', utawa 'atau', banjur 'lalu', terus 'lalu', nanging, ananging 'tetapi, akan tetapi', malah 'justru', mung bae 'hanya, hanya saja', suwalike, kosok baline 'sebaliknya', dan apa 'atau'.

Kajian pustaka yang dilakukan untuk penulisan artikel ini meliputi buku Morfologi Bahasa Jawa (Poedjosoedarmo, 1979), Tata Bahasa Jawa Mutakhir (Wedhawati, dkk., 2006), Tata Bahasa Baku Bahasa Jawa (Sudaryanto, 1991), dan Tipe-tipe Semantik Verba Bahasa Jawa (Wedhawati, dkk., 1990). Selain itu

\footnotetext{
${ }^{4}$ Abdul Chaer, Tata Bahasa Praktis Bahasa Indonesia ....., h. 301.

${ }^{5}$ Harimurti Kridalaksana, Kamus Linguistik, (Jakarta: Gramedia, 1982), h. 71-72.

${ }^{6}$ John Lyons, Introduction to Theoretical Linguistics, (London: Cambridge University Press, 1969), h. 178.

${ }^{7}$ Ramlan, Morfologi ....., h. 43 dan 46.

${ }^{8}$ Gorys Keraf, Tata Bahasa Indonesia, (Ende-Flores: Nusa Indah, 1978), h. 87.
} 
juga menggunakan buku Prinsip-prinsip Dasar Sintaksis (Tarigan, 1981) dan Sintaksis (Ramlan, 1981). Hasil yang ingin dicapai dari penulisan artikel ini adalah menguraikan kajian sintaksis tipe-tipe kalimat majemuk setara dalam bahasa Jawa ngoko.

Berdasarkan latar belakang yang disampaikan di atas, rumusan masalah dapat disampaikan bagaimana tipe-tipe kalimat majemuk setara dalam bahasa Jawa ngoko dari struktur dan sifat hubungan antarklausanya?

Penelitian ini bertujuan untuk mendeskripsikan tipe-tipe kalimat majemuk setara dalam bahasa Jawa ngoko dari struktur dan sifat hubungan antarklausanya.

Hasil penelitian ini akan menunjukkan tipe kalimat majemuk setara dalam bahasa Jawa ngoko dari struktur dan sifat hubungan antarklausanya.

\section{Metode Penelitian}

Data diperoleh dari intuisi penulis sebagai penutur bahasa Jawa dan menyimak perbincangan di lingkungan rumah yang menggunakan tuturan bahasa Jawa,khususnya percakapann dalam bahasa Jawa ngoko. Analisis data dilakukan dengan teknik distribusional dan identitas. Distribusional untuk mengidentifikasi struktur. Teknik identitas untuk menjelaskan konstiyuenkonstituen.

\section{Pembahasan}

\section{Tipe Kalimat Majemuk Setara}

Bahasa Jawa ngoko memiliki kalimat majemuk setara. Kalimat majemuk setara adalah kalimat majemuk yang hubungan antarklausanya sejajar, setara, tidak bawah membawahi. Hubungan antarkalusa itu secara formal dapat ditandai dengan jeda atau kata perangkai lan 'dan', lan uga 'dan (begitu) juga', lan maneh 'dan lagi', sarta 'dan, serta', utawa 'atau', banjur 'lalu', terus 'lalu', nanging, ananging 'tetapi, akan tetapi', malah 'justru', mung bae 'hanya, hanya saja', suwalike, kosok baline 'sebaliknya', tur 'lagi pula', dan apa 'atau'. Contohnya pada kalimat-kalimat berikut.

(1) Aku tangi turu lan adhiku wis rampung adus.

\footnotetext{
${ }^{9}$ Sudaryanto, Metode dan Aneka Teknik Analisis Bahasa: Pengantar Wahana Kebudayaan Secara Linguistik, (Yogyakarta: Duta Wacana University Press, 1993), h. 31 dan 100.
} 
Aku bangun tidur dan adikku sudah selesai mandi.

'Aku bangun tidur dan adikku sudah selesai mandi.'

(2) Pak Gunawan seneng banget lan uga bojone.

Pak Gunawan senang (sekali) dan (begitu) juga istrinya.

'Pak Gunawan sangat senang dan (begitu) juga istrinya.'

(3) Panganan iki enak lan maneh (uga) murah.

Makanan ini enak dan lagi (juga) murah.

'Makanan ini enak dan lagi juga murah.'

(4) Dina kuwi udan deres sarta gludhuge saut-sautan.

Hari itu hujan deras serta petir sambar menyambar.

'Hari itu hujan deras serta petir sambar menyambar.'

(5) Kowe mangkat dhisik utawa adhimu dhisik?

Kamu berangkat dulu atau adikmu lebih dulu?

"Kamu berangkat dulu atau adikmu lebih dulu?'

(6) Dini mangan banjur nggarap pe-er.

Dini makan lalu mengerjakan pekerjaan rumah.

'Dini makan lalu mengerjakan pekerjaan rumah.'

(7) Bubar sinau kelompok, Hani terus dolan.

Selesai belajar kelompok, Hani lalu bermain.

'Selesai belajar kelompok, Hani lalu bermain.'

(8) Wiwin teka ngeterne pelem, nanging ora

Wiwin datang mengantarkan mangga, tetapi tidak

mampir jarene arep kuliah.

mampir katanya mau kuliah.

'Wiwin datang mengantarkan mangga, tetapi tidak mampir katanya mau kuliah.'

(9) Sejatine Linda isih tresna, ananging ora gelem kandha.

Sebetulnya Linda masih cinta, tetapi tidak mau bilang.

'Sebetulnya Linda masih cinta, tetapi tidak mau bilang.'

(10) Karepku arep tangi jam enem, malah kebablasen (nganti)

Niatku mau bangun jam enam, justru keterusan (sampai)

jam sanga esuk.

jam sembilan pagi.

"Niatku mau bangun jam enam, justru keterusan (sampai) jam sembilan pagi.'

(11) Dheweke kepengin dadi dokter, mung bae ora keturutan.

Dia ingin jadi dokter, hanya saja tidak tercapai. 
(Klausa I)

(Klausa II)

(Klausa III)

Aku beli baju dua, Harjono beli sepatu satu, kamu beli apa?

'Aku beli baju dua, Harjono beli sepatu satu, kamu beli apa?'

(16) Omahe gedhong magrong-magrong, sawahe jembar, rajakayane

$\begin{array}{lllll}S & P & S & P & S\end{array}$

(Klausa I)

(Klausa II) (Klausa III)

Rumahnya gedung besar, sawahnya luas, hewan ternaknya akeh. $\mathrm{P}$

banyak.

'Rumah gedungnya besar, sawahnya luas, hewan ternaknya banyak.'

Contoh kalimat (15) - (17) termasuk kalimat majemuk setara dengan tipe sama, terdiri dari dua klausa atau lebih dengan unsur yang lengkap, karena unsur SP di dalamnya lengkap dan dapat dikatakan sebagai klausa bebas karena klausa-klausa tersebut dapat berdiri mandiri sebagai kalimat.

Tipe 2: SP1 + P2 + P3

Tipe kalimat majemuk setara jenis ini, secara fungsional sama dengan tipe sebelumnya, yaitu tipe $\mathrm{SP}(\mathrm{O})(\mathrm{Pel})(\mathrm{K})+\mathrm{SP}(\mathrm{O})(\mathrm{Pel})(\mathrm{K})+\mathrm{SP}(\mathrm{O})(\mathrm{Pel})(\mathrm{K})$. Perbedaannya pada tipe ini, $\mathrm{S}$ pada klausa II dan seterusnya, tidak dinyatakan secara eksplisit atau dilesapkan sehingga dapat ditulis pula dengan SP1 + $\mathrm{P} 2+$ P3. Contohnya sebagai berikut.

(17) Hamengkubuwono IX ajiwa satriya, wanter penggalihe, remen

$\begin{array}{llllllll}S & \text { P1 } & \text { Pel P2 } & \text { Pel } & \text { P3 }\end{array}$

Hamengkubuwono IX berjiwa satria, cerdas pikirannya, gemar tapa brata.

Pel

bertapa.

'Hamengkubuwono IX berjiwa satria, cerdas pikirannya, gemar bertapa.'

Kalimat (18) ini sebenarnya terdiri dari tiga klausa yang utuh, tetapi pada klausa II dan klausa III, S-nya dilesapkan. Dengan demikian, secara formal klausa II dan klausa III hanya bagian-bagian dari klausa. Apabila ditampakkan unsur S-nya, maka kalimat 18 di atas akan menjadi seperti kalimat (18a) di bawah ini. 
(18a) Hamengkubuwono IX ajiwa satriya, Hamengkubowono IX wanter

$\begin{array}{lllll}\text { S1 } & \text { P1 } & \text { Pel } & \text { S2 } & \text { P2 }\end{array}$

'Hamengkubuwono IX berjiwa satria, Hamengkubuwono IX cerdas penggalihe, Hamengkubuwono IX remen tapa brata.

$\begin{array}{llll}\text { Pel } & \text { S3 } & \text { P3 } & \text { Pel }\end{array}$

pikirannya, Hamengkubuwono IX senang bertapa.'

Berdasarkan rekonstruksi pada (18a) dapat dijelaskan bahwa $S$ pada klausa I berfungsi juga sebagai $S$ pada klausa II dan klausa III, sehingga dapat dirumuskan dengan S1,2,3P1 + P2 + P3, dengan catatan $S$ dapat berarti SP, SPO, SPOK, SPK, atau SPPel. Contoh-contoh lainnya yang setipe dengan kalimat (18a) dapat dilihat pada kalimat di bawah ini.

(18) Aku wis teka kawit esuk mau, krasa lungkrah lan lemes nganti Aku sudah datang dari tadi pagi, terasa letih dan lemas sampai ora isa ngglawat.

tidak bisa menggerakkan badan.

'Aku sudah datang dari tadi pagi, terasa letih dan lemas sampai tidak bisa menggerakkan badan.'

(19) Kewan kuwi kaya dene manungsa, butuh ngombe, butuh mangan, lan Binatang itu seperti manusia, perlu minum, perlu makan, dan uga butuh manggon.

juga perlu tempat tinggal.

'Binatang itu seperti manusia, perlu minum, perlu makan, dan juga perlu tempat tinggal.'

Tipe 3: P1 + S1P2 (+ P3)

Tipe ini merupakan perkembangan dari tipe 1 dan tipe 2. Ditinjau dari unsur-unsurnya, tipe ini secara formal sama dengan tipe 2 dan secara semantis sama dengan tipe 1. Perbedaannya, pada tipe ini klausa yang secara formal bebas dan lengkap terletak di tengah kalimat atau di bagian belakang. Contohnya dapat dilihat berikut ini.

(20) Kejaba dirabuk, tanduran lombok ya kudu disirami.

P2 $S \quad P 1$

Selain dipupuk, tanaman cabai juga harus disirami.

'Selain dipupuk, tanaman cabai juga harus disirami.' 
Kalimat (21) terdiri dua klausa. Klausa II merupakan klausa lengkap karena berisi SP dan klausa secara formal tidak lengkap karena hanya berisi P. Sama halnya dengan klausa-klausa yang secara formal tidak lengkap pada kalimat tipe-tipe sebelumnya, klausa yang secara formal tidak lengkap di sini sebenarnya juga merupakan klausa yang lengkap, hanya saja fungsi S-nya dilesapkan. Hal ini dapat dibuktikan dengan merekonstruksi kalimat yang bersangkutan berdasarkan fungsi-fungsinya menjadi seperti berikut.

(21a) Tanduran lombok kejaba dirabuk tanduran lombok ya kudu disirami. $\begin{array}{llll}\text { S2 } & \text { P2 } & \text { S1 } & \text { P1 }\end{array}$

'Tanaman cabai selain dipupuk, tanaman cabai juga harus disirami.'

Kalimat (21a) merupakan rekonstruksi dari kalimat (21) itu tidak lazim karena kaku dan tidak ekonomis. Berdasarkan rekonstruksi semacam itu pula, kalimat tipe ini dapat dirumuskan dengan pola $\mathrm{P}+\mathrm{SP}+(+\mathrm{P} \ldots)$ atau $\mathrm{P} 1+$ $\mathrm{S} 1,2(3, \ldots) \mathrm{P} 2(+\mathrm{P} 3 \ldots)$. Contoh lain yang setipe adalah sebagai berikut.

(21) Umpama dikandhani, dheweke ya mesthi budhal.

Seandainya diberitahu, dia ya pasti berangkat.

'Seandainya diberitahu, dia ya pasti berangkat.'

(22) Masiya wis diundhang bola-bali, dheweke tetep nguncluk mlaku Meskipun sudah dipanggil berkali-kali, dia tetap terus berjalan ora noleh.

tidak menoleh.

'Meskipun sudah dipanggil berkali-kali, dia tetap terus berjalan tidak menoleh.'

Tipe 4: S1P1 + S2

Tipe ini secara formal sekurang-kurangnya terdiri dari dua klausa, klausa I berwujud klausa lengkap, yaitu klausa yang memiliki fungsi $\mathrm{SP}(\mathrm{O})(\mathrm{Pel})(\mathrm{K})$ dan klausa II berwujud klausa yang tidak lengkap, yaitu klausa yang hanya berisi $S$ saja. Tentu saja klausa II kalau direnskontruksikan secara fungsional, akan menjadi klausa lengkap, seperti telah dibuktikan pada tipe-tipe terdahulu. Dengan demikian, penyebutan klausa tidak lengkap di sini hanya berdasarkan struktur formalnya saja. Contohnya adalah sebagai berikut.

(23) Aku durung nate nyang Papua, semono uga adhiku. Aku belum pernah ke Papua, begitu juga (dengan) adikku. 'Aku belum pernah ke Papua, begitu juga (dengan) adikku.' 
Kalimat (24) ini terdiri dari dua klausa. Klausa I, aku durung nate nyang Papua dan klausa II semono uga adhiku. Secara fungsional, aku sebagai pengisi fungsi S, durung nate nyang sebagai fungsi P, Papua sebagai pengisi Pel; sedangkan semono uga berfungsi sebagai konjungsi dan adhiku berfungsi sebagai $S$ pada klausa II. Secara formal klausa kedua itu hanya terdiri dari S saja dan fungsi-fungsi lainnya dilesapkan. Pelesapan fungsi-fungsi lain pada klausa II itu karena fungsi lainnya yang seharusnya ada itu sama dengan yang dimiliki oleh klausa I. Hal itu dapat diketahui dengan munculnya konjungsi semono uga 'begitu juga' sehingga kalimat (24) dapat direkonstruksi sebagai berikut.

(24a) Aku durung nate nyang Papua, semono uga adhiku durung nate nyang Papua.

'Aku belum pernah ke Papua, begitu juga dengan adikku belum pernah ke Papua.'

Dari hasil rekonstruksi itu dapat diketahui bahwa kalimat (24a) itu secara formal berstruktur SPPel + S atau secara fungsional berstruktur SPPel + SPPel. Contoh lain yang setipe dengan (24a) adalah sebagai berikut.

(24) Dhuwit lan sandhangane wis dijaluk kabeh, uga

Uang dan pakaiannya sudah diminta semua, begitu juga sepedha montore.

sepeda motornya.

'Uang dan pakaiannya sudah diminta semuanya, begitu juga sepeda motornya.'

(25) Klambi lan clanane anyar, semono uga sandhale.

Baju dan celananya baru, begitu juga sandalnya.

'Baju dan celananya baru, begitu juga dengan sandalnya.'

Di samping tipe-tipe tersebut di atas, dalam bahasa Jawa ngoko terdapat pula kalimat yang secara formal berstruktur $\mathrm{PPel}(\mathrm{O})+\operatorname{PPel}(\mathrm{O})(+\mathrm{PPel}(\mathrm{O}) \ldots)$. Kalimat tipe ini termasuk kalimat majemuk setara yang secara formal sekurangkurangnya terdiri dari dua klausa yang tidak lengkap. Klausa itu lazimnya hanya berisi $\mathrm{P}$ dan Pel atau $\mathrm{O}$ dan bahkan kadang-kadang hanya berisi $\mathrm{P}$ saja. Meskipun demikian, secara semantis klausa-klausa yang menjadi unsur-unsur kalimat itu lengkap, yaitu ada unsur SP-nya. Kalimat majemuk tipe ini ada dua macam. Pertama, kalimat majemuk setara yang $S$ pada klausa-klausanya dilesapkan dan dapat dikembalikan, seperti contoh (27) dan kedua, kalimat 
majemuk setara yang klausa-klausanya kehilangan S-nya tanpa dapat dikembalikan atau tidak pernah dikembalikan lagi, misalnya pada contoh (28).

(26) Mangan ora, ngombe bae ora.

Makan tidak, minum saja tidak.

'Makan tidak, minum saja tidak.'

(27) Diculke ndhase, digondheli buntute.

Dilepaskan kepalanya, dipegangi ekornya.

'Dilepaskan kepalanya, dipegangi ekornya.'

Kalimat (27) sebenarnya sekurang-kurangnya dapat dilihat dengan dua cara. Pertama, kalimat yang bersangkutan terdiri dari dua klausa yang terdiri dari SP + SP, yaitu klausa I mangan (S) dan ora (P) dan klausa II ngombe bae (S) dan ora (P). Kedua, kalimat yang bersangkutan tidak mempunyai unsur $S$ atau S-nya dilesapkan. Sehubungan dengan hal itu, ini akan diikuti dengan hasil yang kedua, yaitu tipe kalimat yang S-nya dilesapkan mengingat kalimat tersebut kadang-kadang bisa ditambahkan unsur S-nya seperti pada kalimat (27a).

(27a) Dheweke mangan ora, ngombe bae ora.

Dia makan tidak, minum saja tidak.

'Dia makan tidak, minum saja tidak.'

Apa yang ada pada (27a) tidak bisa terjadi pada (28), meskipun kalimat tersebut juga terdiri dari bagian-bagian klausa tanpa unsur $S$, tetapi unsur $S$ itu tidak dapat dikembalikan, atau tidak pernah dinyatakan karena kalimat (28) bersifat idiomatik yang tidak bisa diubah-ubah. Perhatikan (28a) berikut.

(28a)* Dheweke diculke ndhase, nanging digondheli buntute.

Dia dilepaskan kepalanya, tetapi dipegangi ekornya.

'Dia dilepaskan kepalanya, tetapi dipegangi ekornya.'

Kalimat (28a) tidak berterima karena menyalahi aturan idiomatik yang sudah dipakemkan dalam bahasa Jawa. Contoh-contoh lainnya yang setipe dengan (28) misalnya seperti berikut.

(28) Mburu uceng kelangan dheleg.

'Mengejar sesuatu yang kecil, kehilangan sesuatu yang besar.'

(29) Nggutuk elor kena kidul.

'Melempar ke utara mengenai selatan.' 


\section{Kalimat Majemuk Setara Berdasarkan Hubungan Antarklausanya}

Pada bagian sebelumnya telah disebutkan bahwa kalimat majemuk setara mempunyai beberapa alat untuk menghubungkan antara klausa yang satu dengan klausa yang lainnya yang menjadi bagian unsur-unsurnya. Oleh karena itu, hubungan makna antarklausa itu tentu bermacam-macam. Berikut ini adalah tipe-tipe hubungan makna antarklausa majemuk setara dalam bahasa Jawa ngoko.

\section{Hubungan Penjumlahan}

Klausa dalam kalimat majemuk setara dapat memiliki hubungan penjumlahan, yaitu penjumlahan peristiwa, penjumlahan tindakan, atau penjumlahan keadaan. Hubungan tersebut kadang-kadang ditandai dengan jeda atau kata penghubungi, seperti lan 'dan', lan maneh 'dan lagi', sarta 'serta', uga 'juga', lan uga 'dan juga', saliyane kuwi 'selain itu'.

(30) Budi lagi ngresiki komputere, lan adhine lagi

Budi sedang membersihkan komputernya, dan adiknya sedang nonton teve.

nonton televisi.

'Budi sedang membersihkan komputernya, dan adiknya sedang nonton televisi.'

(31) Ngeraha peleme sing akeh, wong wis tuwa-tuwa lan maneh aku ora Petiklah mangga yang banyak, sudah tua-tua dan lagi aku tidak seneng pelem.

senang mangga.

'Petiklah mangga yang banyak, sudah tua-tua dan lagi aku tidak senang mangga.'

(32) Pak Banu, Pak Arif, sarta Pak Doni melu njagong bayi

Pak Banu, Pak Arif, serta Pak Doni ikut datang menengok bayi neng omahe Kamituwa Seno.

di rumah Kamituwa Seno.

'Pak Banu, Pak Arif, serta Pak Doni ikut datang menengok bayi di rumah Kamituwa Seno.'

(33) Dheweke butuh dhuwit uga butuh obat.

Dia perlu uang juga perlu obat.

'Dia perlu uang dan juga perlu obat.' 
(34) Bocahe grapyak semanak, pinter, lan uga ayu pisan. Anaknya ramah, pandai, dan juga cantik (pula).

'Anaknya ramah, pandai, dan juga cantik (pula).'

(35) Bapakku gaweyane saben dina ngolah sawah, ngopeni pitik, Bapakku pekerjaannya setiap hari mengolah sawah, memelihara ayam, saliyane kuwi ya dodolan pakan pitik. selain itu juga berjualan pakan ayam. 'Bapakku pekerjaannya setiap hari mengolah sawah, memelihara ayam, selain itu juga berjualan pakan ayam.’

\section{Hubungan Pilihan}

Hubungan antarklausa dikatakan sebagai hubungan pilihan kalau yang merupakan kenyataan hanya salah satu dari yang tersebut pada klausa dalam kaliamat tersebut. Biasanya ditandai dengan jeda atau konjungsi utawa 'atau' dan apa 'apakah, atau'. Apabila hubungan pilihannya sudah jelas, biasanya hanya menggunakan tanda jeda, seperti kalimat (37). Apabila dapat menimbulkan perbedaan persepsi, maka hubungannya ditandai dengan konjungsi utawa, contoh kalimat (38). Sementara itu, konjungsi apa untuk menyatakan hubungan pilihan dalam kalimat tanya, seperti kalimat (39).

(36) Kowe arep lunga, kowe arep mulih, aku wis ora urus.

Kamu mau pergi, kamu mau pulang, aku sudah tidak peduli.

'Kamu mau pergi, kamu mau pulang, aku sudah tidak peduli.'

(37) Kowe mulih saiki utawa sesuk padha bae, wong dheweke wis budhal kawit mau.

'Kamu pulang sekarang atau besok sama saja, lha dia sudah berangkat dari tadi.'

(38) Kowe wis mangan apa durung?

Kamu sudah makan atau belum?

'Kamu sudah makan atau belum?'

\section{Hubungan Perlawanan}

Hubungan makna antarklausa dikatakan bersifat perlawanan kalau apa yang dimaksudkan di dalam klausa yang satu dengan klausa yang lain, berlawanan atau bertolak belakang. Hubungan makna tipe ini dapat dinyatakan dengan konjungsi nanging 'tetapi' atau ananging 'tetapi', mangka 'padahal', kamangka 'padahal', suwalike 'sebaliknya', kosokbaline 'sebaliknya', atau mung 'hanya'. Contohnya ada di bawah ini. 
(39) Wingi aku liwat ngomahmu, nanging ora mampir wong Kemarin aku lewat rumahmu, tetapi tidak mampir (karena) wis bengi.

sudah malam.

'Kemarin aku lewat rumahmu, tetapi tidak mampir karena sudah malam.' (40) Andri ora teka, mangka wis takkandhani bola-bali. Andri tidak datang, padahal sudah kuberitahu berkali-kali. 'Andri tidak datang, padahal sudah kuberitahu berkali-kali.'

(41) Dheweke sregep, suwalike adhine kesed.

Dia rajin, sebaliknya adiknya malas.

'Dia rajin, sebaliknya adiknya malas.'

(42) Dheweke dudu masku kandhung, mung sedulur misan.

Dia bukan kakak (lelaki) kandungku, hanya saudara sepupu.

Dia bukan kakak (lelaki) kandungku, hanya saudara sepupu.

\section{Hubungan Berlebihan}

Hubungan antar klausa kalimat majemuk tipe ini menyatakan makna berlebihan. Makna klausa yang satu melebihi dari makna klausa lainnya. Hubungan makna berlebihan ini ditandai dengan konjungsi malah 'justru'. Klausa yang berada di belakang konjungsi itulah yang menyatakan makna lebih dari klausa sebelumnya.

(43) Dheweke sing paling dhuwur, malahan paling dhuwur neng Dia yang paling tinggi, justru paling tinggi di keluargane. keluarganya.

'Dia yang paling tinggi, justru paling tinggi di keluarganya.'

(44) Pak Alif gati banget karo aku, malah nganggep kaya

Pak Alif sayang sekali kepadaku, malah menganggap seperti

anake dhewe.

anaknya sendiri.

'Pak Alif sayang sekali kepadaku, malah menganggap (aku) seperti anaknya sendiri.'

\section{Hubungan Berkesinambungan atau Terus Menerus}

Tipe ini menyatakan hubungan kesinambungan suatu peristiwa, keadaan atau perbuatan yang dinyatakan pada klausa satu dengan klausa lainnya. 
Hubungan itu dapat dinyatakan dengan konjungsi terus 'terus', banjur 'kemudian', sabanjure 'selanjutnya'. Contohnya pada kalimat-kalimat berikut.

(45) Dheweke tangi gasik, adus, dandan, banjur lunga.

Dia bangun pagi, mandi, berdandan, terus pergi.

'Dia bangun pagi, mandi, berdandan, terus pergi.'

(46) Wis ora usah takon, tukokna bae terus menehna dheweke.

Sudah tidak usah bertanya, belikan saja terus berikan pada dia.

'Sudah tidak usah tanya, belikan saja terus berikan pada dia.'

(47) Sing tak ngerteni Sulis isih kuliah neng Surabaya sasi wingi, Yang aku tahu Sulis masih kuliah di Surabaya bulan kemarin, sabanjure akuora tau ketemu. selanjutnya aku tidak pernah ketemu.

'Yang aku tahu Sulis masih kuliah di Surabaya bulan kemarin, seterusnya aku tidak pernah ketemu.'

\section{Simpulan}

Dalam bahasa Jawa ngoko terdapat kalimat yang terdiri dari dua klausa atau lebih yang setara disebut dengan kalimat majemuk setara. Kalimat majemuk setara adalah kalimat majemuk yang hubungan antarklausanya sejajar, sepadan, atau seimbang. Di dalam kalimat majemuk setara ada dua hal utama, yaitu berdasarkan strukturnya dapat dibedakan menjadi 4 jenis, yaitu:

1. $\mathrm{SP}(\mathrm{O})(\mathrm{Pel})(\mathrm{K})+\mathrm{SP}(\mathrm{O})(\mathrm{Pel})(\mathrm{K})+\mathrm{SP}(\mathrm{O})(\mathrm{Pel})(\mathrm{K})$

2. $\mathrm{SP} 1+\mathrm{P} 2+\mathrm{P} 3$

3. $\mathrm{P} 1+\mathrm{S} 1 \mathrm{P} 2(+\mathrm{P} 3)$

4. $\mathrm{S} 1 \mathrm{P} 1+\mathrm{S} 2$

Sedangkan berdasarkan hubungan antar klausanya, kalimat majemuk setara bahasa Jawa ngoko dapat dibedakan menjadi 5 jenis, yaitu: Hubungan penjumlahan; Hubungan pilihan; Hubungan perlawanan; Hubungan berlebihan; Hubungan berkesinambungan atau terus menerus.

\section{Daftar Pustaka}

Chaer, Abdul. 1998. Tata Bahasa Praktis Bahasa Indonesia. Edisi Revisi. Jakarta: Penerbit Rineka Cipta.

Keraf, Gorys. 1978. Tata Bahasa Indonesia. Ende-Flores: Nusa Indah. 
Kridalaksana, Harimurti. 1982. Kamus Linguistik. Jakarta: Gramedia.

Lyons, John. 1971. Introduction to Theoretical Linguistics. London: Cambridge University Pres.

Poedjosoedarmo, Soepomo. 1979. Morfologi Bahasa Jawa. Jakarta: Pusat Pembinaan dan Pengembangan Bahasa, Departemen Pendidikan dan Kebudayaan.

Ramlan, M. 1981. Sintaksis. Yogyakarta: Karyono.

-----. 1996. Morfologi. Yogyakarta: Karyono.

Sudaryanto (Penyunting). 1991. Tata Bahasa Baku Bahasa Jawa. Yogyakarta: Duta Wacana University Press.

1993. Metode dan Aneka Teknik Analisis Bahasa: Pengantar Wahana Kebudayaan Secara Linguistik. Yogyakarta: Duta Wacana University Press.

Tarigan, Henry Guntur. 1981. Prinsip-prinsip Dasar Sintaksis. Bandung: Angkasa.

Wedhawati, dkk. 2006. Tata Bahasa Jawa Mutakhir. Yogyakarta: Penerbit Kanisius.

------. 1990. Tipe-tipe Semantik Verba Bahasa Jawa. Jakarta: Pusat Pembinaan dan Pengembangan Bahasa. Departemen Pendidikan dan Kebudayaan. 